\section{Critical Soil Moisture Levels for Field Planting Fourwing Saltbush $^{1}$}

\author{
EARL F. ALDON
}

\begin{abstract}
Hydrologist, Rocky Mountain Forest and Range Experimenl Station, 2 Albuquerque, New Mexico
\end{abstract}

\section{Highlight}

Survival of fourwing saltbush transplants was at least $80 \%$ when alluvial field sites had soil moisture levels of at least $14 \%$ by weight or were at tensions between $1 / 3$ and 2 atmospheres.

Recently, much effort has gone into determining methods of establishing fourwing saltbush (Atriplex canescens (Pursh) Nutt.) on devastated areas in need of soil stabilization (Aldon, 1970a, b, c; Springfield, 1970). There are many reasons for this effort: fourwing saltbush is an excellent soil stabilizer, a nutritious all-season forage plant for grazing animals, provides food and cover for wildlife, and traps sediment on alluvial flood plains.

Three-month-old fourwing saltbush transplants grown from a native source can be successfully field planted with up to $80 \%$ survival. The transplants need to be grown by certain techniques, and field planted in special ways (Aldon, 1970a, b, c). One study showed soil moisture at planting time was a critical factor in survival of transplants (Aldon, 1970a), but the amount of moisture needed was not known. This study, located in north central New Mexico, was designed to determine what minimum levels of soil moisture are needed for successful field plantings of fourwing saltbush.

\footnotetext{
${ }^{1}$ Study conducted in cooperation with Bureau of Land Management, U.S. Dep. of The Interior, Albuquerque, New Mexico. Received August 18, 1971.

${ }^{2}$ Principal Hydrologist, located at Albuquerque in cooperation with the University of New Mexico; central headquarters maintained at Fort Collins in cooperation with Colorado State University.
}

\section{Methods}

Six different alluvial bottom sites were planted in the summers of 1968 and 1969. These alluvial land sites have deep, granular soil with textures ranging from loamy fine sand to loam (Folks and Stone, 1968). In 1968, sites were planted before and after they had been flooded by summer storms. Based on 1968 findings, the 1969 sites were planted only after they had been flooded. In 1970, two additional alluvial bottom sites were planted.

At all sites in all years, 10 threemonth-old transplants were used. They were all grown from the same local seed source and planted at the same depth in the same way. Survival was measured at the end of the first growing season.

At the time of each planting, a linch core of soil was taken at the bottom (about 5 inches deep) of five randomly selected planting holes, and soil moisture was determined gravcmetrically. Soil samples were also taken on the six 1968 and 1969 sites, and drying curves were prepared from data obtained with a pressurc mombrane apparatus.

A probit transformation was made of survival data, and soil moisture percentages were transformed to logarithms for regression analysis (Finney, 1964). A 5\% level of probability was accepted for significance.

\section{Results}

Eighty percent survival was attained when fourwing saltbush transplants were planted on alluvial soils containing at least $14 \%$ soil moisture by weight (Fig. 1). These alluvial soils were at moisture stresses between $1 / 3$ and $2 \mathrm{~atm}$ of tension at that time (Fig. 2).

Not all data were used in the analyses. Plants on several sites were flooded for over 40 hours, and all died. Mortality increases with time submerged (Aldon, 1970c). One site, with low soil moisture at planting (10.4\%), was flooded the next day. Because survival was $100 \%$ due to this flooding, the site was omitted from the sample.

Moisture characteristics of the six sites differed by only a few percent at each tested tension level. A typical

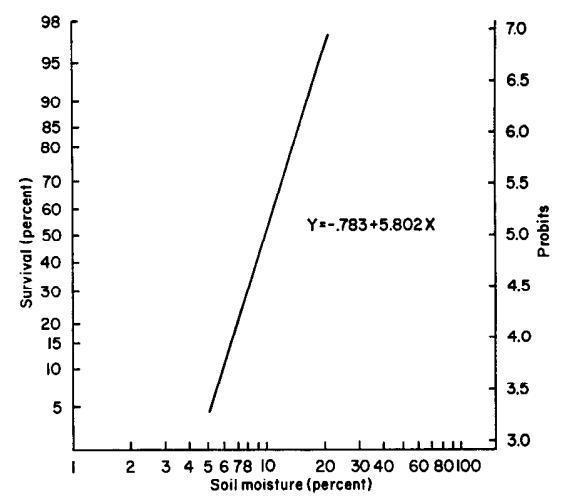

FIg. 1. Relationship between percent soil moisture and survival of young fourwing saltbush plants.

curve was drawn from the data (Fig. 2) for comparative purposes with other potential planting sites. If a drying curve from a potential planting site differed little from Figure 2 these field soil moisture percentages could be used. Other percentages would have to be determined if curves were much different.

To successfully plant fourwing saltbush transplants on alluvial flood plains in the Southwest, it is important to wait until the probability for sizable (.40 inch plus) summer thunderstorms

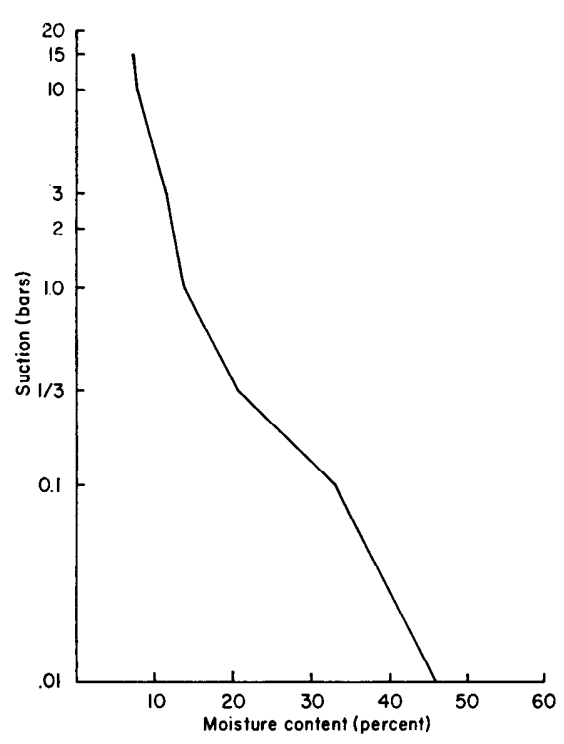

Fig. 2. Typical drying curve for six alluvial flood plain sites. 
exceeds 50\% (Gifford et al., 1967) and soil moisture stress is less than $2 \mathrm{~atm}$ of tension. For alluvial bottom lands, this is about $13 \%$ soil moisture. Using native seed for the transplants and placing them at ground level is also important for good survival (Aldon, 1970a).

\section{Literature Cited}

Aldon, Earl F. 1970a. Fourwing saltbush can be field planted successfully. USDA Forest Serv. Res. Note RM-173, 2 p. Rocky Mt. Forest and Range Exp. Sta., Fort Collins, Colo.
Aldon, EARL F. 1970b. Growing fourwing saltbush transplants for field planting. USDA Forest Serv. Res. Note RM-161, 3 p. Rocky Mt. Forest and Range Exp. Sta., Fort Collins, Colo.

Aldon, Earl F. 1970c. Fourwing saltbush survival after inundation. USDA Forest Serv. Res. Note RM165, 2 p. Rocky Mt. Forest and Range Exp. Sta., Fort Collins, Colo.

Finney, D. J. 1964. Statistical method in biological assay. Ed. 2, New York: IIafner Publ. Co. 668 p.

Fot.ks, J. J., and W. B. Stone. 1968.
Soil Survey, Cabezon Area, New Mexico. U.S. Soil Conserv. Serv., $44 \mathrm{p}$.

Gifford, R. P., G. L. AshCroft, And M. D. MAgnuson. 1967. Probability of selected precipitation amounts in the Western region of the United States. Univ. of Nev., Agr. Exp. Sta. Rep. T-8.

Springrield, H. W. 1970. Germination and establishment of fourwing saltbush in the Southwest. USDA Forest Serv. Res. Pap. RM-55, 48 p. Rocky Mt. Forest and Range Exp. Sta., Fort Collins, Colo. 